\title{
Who Deserves a Ventilator Amidst the Covid-19 Pandemic? Sorting the Moral, Ethical and Legal Dilemma in Indian Scenario
}

\author{
Priyanka Mishra MD*1 and Amborish Nath $\mathrm{MCH}^{2}$ \\ ${ }^{1}$ Department of Anesthesia, All India Institute of Medical Sciences (AIIMS), Rishikesh, Uttarakhand, India. \\ ${ }^{2}$ Department of Plastic Surgery, All India Institute of Medical Sciences (AIIMS), Rishikesh, Uttarakhand, India.
}

*Corresponding Author: Priyanka Mishra, Department of Anesthesia, All India Institute of Medical Sciences (AIIMS), Rishikesh, Uttarakhand, India.

\section{Received Date: July 26, 2021 | Accepted Date: September 18, 2021 | Published Date: September 27, 2021}

Citation: P Mishra and A Nath. (2021). Who Deserves a Ventilator amidst the Covid-19 Pandemic? Sorting the Moral, Ethical and Legal Dilemma in Indian Scenario. International Journal of Clinical Case Reports and Reviews. 8(4); DOI:10.31579/2690-4861/158

Copyright: () 2021 Priyanka Mishra, This is an open-access article distributed under the terms of the Creative Commons Attribution License, which permits unrestricted use, distribution, and reproduction in any medium, provided the original author and source are credited.

\begin{abstract}
The novel coronavirus disease (COVID-19) has rampaged into a second wave and shook the health infrastructure of several countries with India being among one of the worst-hit nations. In consideration of the current immense scarcity of ventilators in India, cautious resource allocation is the need of the hour. Hence, the Intensive care units and the ventilator allocation triage need to be formulated by a central public policy. This is due to the clinical implications, subjective judgments, ethical controversy, evidentiary weaknesses, and organizational complexities. This article suggests few approaches to suitably acknowledge everyone's rights and judiciously allocate the ventilators for maximum benefit. This will ensure that the "maximum life years" are saved and no patient dies unlawfully.
\end{abstract}

Keywords- COVID-19; ventilator; India; resource allocation

\section{Introduction}

The novel coronavirus disease (COVID-19) has rampaged into a second wave and shook the health infrastructure of countries throughout the world. Despite the fact that the disease presents as an asymptomatic or mild state in the majority of patients, there is a subset of patients requiring ICU admission and non-invasive or invasive ventilatory support [1].

India is witnessing up to 400,000 new infections every day. In a country of 1.39 billion people, with 8.5 hospital beds per 10,000 population, the country's healthcare sector is not equipped to handle this crisis. According to the Brookings reports and the statement passed by the ministry of health and family welfare (in India, till January 2021, the estimated number of ventilators in the country currently are at a maximum of 57000 . However, at the current rate of infection, India may need up to 110 000-220 000 ventilators $[2,3]$. In consideration of this immense scarcity of ventilators, cautious resource allocation is the need of the hour. Hence, rationing the ventilators and making the difficult decision of initiating and withdrawing the ventilator support for a specific group of patients will be needed. The current gold standard is for the triage teams to take such decisions independently or in communication with the frontline healthcare workers (HCW). However, the professional and ethical dilemma encountered by the health caregiver, in absence of a clear protocol, accompanied with the anguish and discontent of the patient's relatives on the decision of withdrawal or denial of ventilator support to their patient, is something to reckon with.

Currently, the ministry of health and family welfare in India has published management guidelines for adult critical care in COVID patients, but there is no blueprint for withholding or withdrawing ventilators. We believe that rather than resting the decision with respective institutes, India needs to form a national public policy to govern this sensitive decision.

Following the footsteps of Italy where the Italian National Committee for Bioethics (Comitato Nazionale per la Bioetica, hence CNB) gave out clear "Clinical decision-making in conditions of resource shortage", India needs to follow the suit [4]. The ICU and hence ventilator allocation triage needs to be formulated with due consideration to the clinical implications, subjective judgments, ethical controversy, evidentiary weaknesses, and organizational complexities. We hereby suggest the approaches that can help us suitably acknowledge everyone's rights and also judiciously allocate the ventilators amidst the pandemic.

1. Triage tools for ventilator allocation- Despite the controversy regarding inclusion of age in the criteria of resource allocation, we strongly believe that the most appropriate model rests on the save "maximum lives/life-years" criteria which is more focused on harmonizing both short and long term death [5]. There is a major 
operational approach of prioritizing the younger patients with more life years at hand over the elderly, but there is no clear guideline available in India.

2. Step-ladder technique of decision making- This includes assessment for exclusion criteria, followed by determination of priority for ventilator allocation and subsequent repeat assessments to decide on continuation or withdrawal of the ventilatory support. The exclusion criteria can be based on using the Sequential Organ Failure Assessment (SOFA) score for mortality risk assessment, the presence of an irreversible shock, Acute Physiology, and Chronic Health Evaluation (Apache II) scores, etc [6].

3. Counselling and support teams - The pro-active counseling teams should discuss with both the patients and the families regarding the "do-not-intubate" and "do-not-resuscitate" orders for the patients falling in high-risk subgroups. The committee members shall communicate the decisions while providing an accurate representation of intentions and motive. A clear message should be delivered that mechanical ventilation is not going to improve the prognosis and might simply prolong the patient agony. They shall also be well informed about the national guidelines regarding the same to prevent any distrust and misunderstandings.

4. Palliative care committees- It is imperative to ensure that the human rights of the patients falling in the exclusion group for ventilator allocation are well respected. Palliative care teams shall serve to mitigate the pain and suffering and provide the best emotional support to such patients at the end of life.

5. Safeguarding occupational health of HCW- In the current scenario, the caregivers are already susceptible to a substantial amount of emotional and physical exhaustion. This bears even more significance in a country like India, where the acts of violence against doctors have become a rising menace [7]. Despite the Medical Protection Act (MPA) which has been implemented across many states in India, the incidents of assault against doctors have taken a monstrous turn in the pandemic time. As per a study by the Indian Medical Association (IMA), as high as, 75 percent of the doctors in India have faced violence, mostly in the form of

\section{References}

1. Serafim RB, Póvoa P, Souza-Dantas V, Kalil AC, Salluh JIF. (2021). Clinical course and outcomes of critically ill patients with COVID-19 infection: a systematic review. Clin Microbiol Infect. 27(1):47-54.

2. Singh P, Ravi S, Chakraborty S. (2020). COVID-19 is India's health infrastructure equipped to handle an epidemic? Brooking India.

3. Department Of Health and family welfare. 2021.

4. Italian National Bioethics Committee Opinion 'Covid 19: clinical decision-making in conditions of resource shortage and the "pandemic emergency triage" criterion'. 2020.

5. Goldstein JR, Cassidy T, Wachter KW. (2021). Vaccinating the oldest against COVID-19 saves both the most lives and most years of life. Proc Natl Acad Sci U S A. 118(11):2026322118. verbal abuse, at some point of time in their professional career [8]. A concrete set of written recommendations will contribute to mitigating the ill effects on their occupational health and buffer clinicians from such potential abuse.

Moreover, witnessing the high mortality and poor prognosis in most of the patients contributes to depression among the HCW. A protocol towards saving "more life years" will result in better patient outcomes, which will also boost up the morale of health care workers working endlessly in this pandemic.

6. The role of an ethical body: India needs to organize a medically and legally aware ethical committee to lay down the constitution of allocation of resources, keeping into account the rights and requirements of the patients. While allocating the life-saving resources, the patient's legal rights shall not be undermined as well. India needs to pass a central legislature suggesting that the decisions for scarce resource allocation be based on the patient's comparative 'capacity to benefit quickly', and the outcome can be in the form of withholding or denial of specific treatment to the patients with poorer prognosis [9]. We need to give due consideration to the relevant legal dilemmas including Human rights law, Criminal law, Civil law, Lawson decision-making for incapacitated adults, Professional regulations, and the Public and administrative laws. The ventilator allocation policies need to directly engage with all these legal issues briefly discussed by Liddell et also as to protect the medical fraternity from wrongful medical malpractice lawsuits while ensuring that the patients do not die unlawfully [10].

This pandemic is unprecedented and it brings us new dilemmas with every passing day. The lack of a clear consensus between the criteria for allocation of the life-saving resources in a pandemic is a crucial challenge, with the possible involvement of several competing interests. In the current need for scarce resource allocation like ventilators, a concrete written central policy by India can contribute to mitigating the rising scrutiny with regard to the same. This will ensure that the "maximum life years" are saved and everybody's rights are well respected.

6. Camporesi S, and Mori M. (2020). Ethicists, doctors and triage decisions: who should decide? And on what basis? Journal of Medical Ethics.

7. Sakthivel P, Rajeshwari M, Malhotra N, Ish P. (2020). Violence against doctors: an emerging epidemic amidst COVID-19 pandemic in India. Postgrad Med J.

8. Ghosh K. (2018). Violence against doctors: A wake-up call. Indian J Med Res. 148(2):130-133.

9. British Medical Association COVID-19-Ethical issues. (2020). A guidance note.

10. Liddell K, Skopek JM, Palmer S, Martin S, Anderson J, Sagar A. (2020). Who gets the ventilator? Important legal rights in a pandemic. J Med Ethics. 46(7):421-426. 
This work is licensed under Creative Commons Attribution 4.0 License

To Submit Your Article Click Here: Submit Manuscript

DOI: $10.31579 / 2690-4861 / 158$
Ready to submit your research? Choose Auctores and benefit from:

$>$ fast, convenient online submission

$>$ rigorous peer review by experienced research in your field

$>$ rapid publication on acceptance

$>$ authors retain copyrights

$>$ unique DOI for all articles

$>$ immediate, unrestricted online access

At Auctores, research is always in progress.

Learn more https://auctoresonline.org/journals/international-journal-ofclinical-case-reports-and-reviews 